OPEN ACCESS

Edited by:

Miroslav Nikolic

University of Belgrade, Serbia

Reviewed by:

Ivana Maksimovic,

University of Novi Sad, Serbia

Haijun Gong,

Northwest A\&F University, China

*Correspondence:

Dehua Chen

cdh@yzu.edu.cn

Specialty section: This article was submitted to

Plant Nutrition,

a section of the journal

Frontiers in Plant Science

Received: 25 October 2017 Accepted: 10 January 2018

Published: 30 January 2018

Citation:

Chen Y, Li Y, Zhou M, Rui Q, Cai Z, Zhang X, Chen Y and Chen D (2018)

Nitrogen (N) Application Gradually

Enhances Boll Development and

Decreases Boll Shell Insecticidal

Protein Content in N-Deficient Cotton.

Front. Plant Sci. 9:51

doi: $10.3389 / \mathrm{fp} / \mathrm{s} .2018 .00051$

\section{Nitrogen (N) Application Gradually Enhances Boll Development and Decreases Boll Shell Insecticidal Protein Content in N-Deficient Cotton}

\author{
Yuan Chen ${ }^{1}$, Yabing Li $^{2}$, Mingyuan Zhou ${ }^{1}$, Qiuzhi Rui ${ }^{1}$, Zezhou Cai ${ }^{1}$, Xiang Zhang ${ }^{1}$, \\ Yuan Chen ${ }^{1}$ and Dehua Chen ${ }^{1 *}$
}

1 Jiangsu Key Laboratory of Crop Genetics and Physiology, Co-Innovation Center for Modern Production Technology of Grain Crops, Yangzhou University, Yangzhou, China, ${ }^{2}$ State Key Laboratory of Cotton Biology, Institute of Cotton Research of the

Chinese Academy of Agricultural Sciences, Henan, China

Expression of insecticidal protein in transgenic Bacillus thuringiensis (Bt) is lower in cotton reproduction organs, especially during boll development period. The current study investigated the effects of nitrogen fertilization under nitrogen deficit on boll development and Bt toxin content in boll shell, which is the first target of boll worm harm. The protein synthesis and degradation in this process was also studied to uncover the underlying mechanism. Five nitrogen levels (under nitrogen deficiency) were imposed on two cultivars, Sikang3 (hybrid) and Sikang1 (conventional), at the Yangzhou University Farm, Yangzhou, China during 2015 to 2016 cotton growth seasons. Under nitrogen deficiency, enhanced nitrogen dose increased the boll number per plant, boll volume, boll weight, boll shell amino acid content, protease, and peptidase activities, but reduced boll shell Bt protein content, soluble protein content, glutamic pyruvic transaminase (GPT) and glutamate oxaloacetate transaminase (GOT) activities. There was a significant negative correlation between boll growth and boll shell insecticidal protein content under nitrogen deficiency, which was a result of uneven distribution of nitrogen in cotton bolls. Under increased nitrogen application, most nitrogen was transported and assimilated in boll seed instead of boll shell in developing cotton bolls, which resulted in decreased protein synthesis and increased protein degradation, and thus declined Bt protein content in boll shell.

Keywords: Bt insecticidal protein, nitrogen application dose, boll development, nitrogen metabolism, Bt cotton

\section{INTRODUCTION}

The production of Bacillus Thuringiensis (Bt) transgenic cotton decreased environmental pollution, increased worker safety by reduced chemical use, and enhanced grower income (Gould, 1988; Gasser and Fraley, 1989; Huang et al., 2010). The Bt cotton can encode the CryIAc protein to control the harm of Helicoverpa amigera larvae. However, the insecticidal activity is unstable, variation of insect efficiency due to altered CryIAc expression has been related to the extreme environmental factors, the silence or switch off of introduced gene, and/or developmental stage (Benedict et al., 1993; Xia and Guo, 2004; Wang et al., 2009; Chen et al., 2012a,b). Along with variance due to environmental factors, the variance of insect efficiency was also observed at different growth stages 
and different organs. Higher insect resistance to boll worm has been shown to appear at early growing stages, whereas the periods of the yield formation recorded lowest insect efficiency (Li et al., 2006; Zhang and Wen, 2011). The leaves, especially the younger leaves, had higher insect resistance than other organs of the Bt cotton plant, and in contrast the bolls exhibited lowest insect efficiency of all reproductive organs (Shen et al., 2010; Stone, 2011). Our previous studies found that cultivars and leaf-square regulation affected boll size, which contributed to changed Bt toxin protein content (Wang et al., 2009), but the mechanism is still unknown. Our previous studies also observed that the Bt insecticidal efficacy was associated with nitrogen metabolism, and the Bt toxin content was impacted by protein synthesis and degradation process (Zhang et al., 2007; Chen et al., 2017). Thus, the altered Bt protein content caused by boll development may be explained by the nitrogen metabolism in this process. It was reported that optimal nitrogen fertilization caused larger bolls and ultimately a higher yield (Boquet et al., 1994; Mcconnell et al., 1998; Moore, 1999; Boquet and Breitenbeck, 2000). Improvement of leave insecticidal protein through the application of high dose of nitrogen was reported in Bt cotton (Yang et al., 2005; Pettigrew and Adamczyk, 2006; Dong et al., 2007; Zhang and Wen, 2011; Dai et al., 2012; Manjunatha, 2015), but little is known about the effect of nitrogen application on cotton boll Bt content. Since nitrogen fertilization plays an important role in both boll development and Bt toxin content, in order to uncover the mechanism of the impact of boll size on insect resistance, it is necessary to study the effect of nitrogen fertilization on both Bt toxin content and boll development.

The current study tested the effect of nitrogen fertilization under nitrogen deficiency on the boll shell insecticidal protein concentration and boll development. And by investigating the protein synthesis and degradation, we tried to uncover the potential mechanism to explain the relationship of boll development and insecticidal protein content in boll shell.

\section{MATERIALS AND METHODS}

\section{Materials and Experimental Design}

Field experiments were carried out at Yangzhou University Farm, Jiangsu Province, China $\left(32^{\circ} 30^{\prime} \mathrm{N}, 119^{\circ} 25^{\prime} \mathrm{E}\right)$ in $2015-2016$. Sikang1 (conventional) and Sikang3 (hybrid), which are two widely grown Bt cotton cultivars in China, were used in this study with the planting density of 27,000 (Sikang3) and 37,500 (Sikang1) plant per hectare. Seeds were sown on April 3rd (2015) and April 7th (2016) in a plastic cover lilliputian greenhouse. Seedlings were transplanted to the field on May 15th (2015) and May 19th (2016). The soil [sandy loam texture (Typical fluvaquents, Entisols (U.S. taxonomy))] contained 22.3 and $21.9 \mathrm{~g} \mathrm{~kg}^{-1}$ organic matter and 110.5 and 113.7, 21.6 and 20.9, 85.6 and $86.8 \mathrm{mg} \mathrm{kg}^{-1}$ available N-P-K in 2015 and 2016 , respectively. Cultivation practices, including application of fertilizers and insecticides, chemical plant growth retardant DPC (1,1-dimethyl piperidinium chloride, C7H16CIN) spray, and irrigation, were carried out following local recommendations. Before planting, $\mathrm{K}\left(120 \mathrm{~kg} \mathrm{ha}^{-1}\right.$ as $\left.\mathrm{KCl}\right)$ and $\mathrm{P}\left(300 \mathrm{~kg} \mathrm{ha}^{-1}\right.$ as single superphosphate) were applied. At early flowering, $\mathrm{K}\left(120 \mathrm{~kg} \mathrm{ha}^{-1}\right.$ as $\left.\mathrm{KCl}\right)$ and $\mathrm{P}\left(300 \mathrm{~kg} \mathrm{ha}^{-1}\right.$ as single superphosphate) were top-dressed. $\mathrm{N}$ (urea) was applied before transplanting (25\%), at early flowering (18\%), and at peak flowering (57\%).

In 2015 and 2016, the experiment was arranged with split plot designs. The main plot treatment was cultivars (Sikang1 and Sikang2), and the subplot treatment consisted of five nitrogen application dose $\left(0,75,150,225\right.$, and $\left.300 \mathrm{~kg} \mathrm{ha}^{-1}\right)$. Three hundred $\mathrm{kg} \mathrm{ha}^{-1}$ is the nitrogen fertilization dose recommended for cotton production in local area. Three replications were used in the field. Each plot consisted of $6-\mathrm{m}$ rows spaced $0.9 \mathrm{~m}$ apart.

\section{Preparation of Plant Material and Boll Development Measurements}

The boll number per plant, boll size, boll shell CryIAc insecticidal protein contents and nitrogen metabolic chemicals at 10, 20, 30, and 40 days after flowering (DAF) were measured during the boll stage. At each sampling time, the boll number of 10 plants per plot were counted. For each plot, 15 bolls were harvested from the first position of the fourth to sixth fruiting branches for further analysis. By soaking the boll into water in a marked cylinder, the boll volume was calculated as the amount of water displacement immediately after harvest.

\section{The Cryiac Protein Content}

Immunological analysis ELISA was used to test the CryIAc content in the cotton boll shell extracts as described by Chen et al. (1997). Three subsamples of boll shell ( $0.2 \mathrm{~g} \mathrm{FW)} \mathrm{per} \mathrm{each} \mathrm{plot}$ were used to determine the toxin protein content.

\section{Free Amino Acid and Soluble Protein Content}

Based on Yemm et al. (1955), analysis of the total free amino acid content was measured by ninhydrin assay. The Coomassie Blue dye-binding assay of Bradford was used for total soluble protein content determination (Bradford, 1976).

\section{Glutamic-Pyruvic Transaminase (GPT) and Glutamate Oxaloacetate Transaminase (GOT) Activity}

Boll shells ( $0.2 \mathrm{~g}$ FW) were homogenized in $0.05 \mathrm{mM}$ Tris- $\mathrm{HCl}$, $\mathrm{pH} 7.2$ buffer. The supernatant was collected after centrifugation at $26,100 \mathrm{~g}$ for $10 \mathrm{~min}$ at $4^{\circ} \mathrm{C}$. For GOT activity assay, $0.2 \mathrm{~mL}$ of the supernatant was added to a mixture containing $0.5 \mathrm{~mL}$ of $0.8 \mathrm{M}$ alanine in $0.1 \mathrm{M}$ Tris- $\mathrm{HCl}(\mathrm{pH} 7.5), 0.1 \mathrm{~mL}$ of $2 \mathrm{mM}$ pyriodoxal phosphate solution, and $0.2 \mathrm{~mL}$ of $0.1 \mathrm{M}$ 2-oxoglutarate solution. The reaction mixture was incubated at $37^{\circ} \mathrm{C}$ for $10 \mathrm{~min}$ followed by adding $0.1 \mathrm{ml}$ of a $0.2 \mathrm{M}$ trichloroacetic acid solution to stop the reaction. The color intensity was read at $520 \mathrm{~nm}$. The GPT activity assay was similar to the GOT assay. In GPT assay, $0.5 \mathrm{ml}$ of a $0.1 \mathrm{M}$ buffered aspartate solution in the reaction mixture was used instead of $0.5 \mathrm{ml}$ of a $0.8 \mathrm{M}$ alanine in $0.1 \mathrm{M}$ Tris- $\mathrm{HCl}$ ( $\mathrm{pH} 7.5$ ) (Tonhazy et al., 1950). 


\section{Protease and Peptidase Activity}

Boll shells $(0.8 \mathrm{~g})$ were homogenized at $4^{\circ} \mathrm{C}$ in $1 \mathrm{ml}$ of $\beta$-mercaptoethanol extraction buffer (a mixture of ethylene glycol, sucrose, and phenylmethylsulfonyl fluoride $\mathrm{pH}$ 6.8). The supernatant was collected to estimate the square protease. Protease activity was determined spectrophotometrically at $400 \mathrm{~nm}$ using azocasein as a substrate (Vance and Johnson, 1979) and expressed as mg protein $\mathrm{g}^{-1}$ boll shell fresh weight (FW) $\mathrm{h}^{-1}$.

Boll shell samples $(0.5 \mathrm{~g})$ were homogenized at $4^{\circ} \mathrm{C}$ in $8 \mathrm{ml}$ of Tris- $\mathrm{HCl}$ extraction buffer (a mixture of $4 \mathrm{mM}$ DTT, $4 \mathrm{mM}$ EDTA, 1\% PVP, pH 7.5). The supernatant $(0.4 \mathrm{ml})$ was collected by centrifugation at $15,000 \mathrm{~g}$ for $30 \mathrm{~min}$ at $4^{\circ} \mathrm{C}$ and added to a mixture $[0.4 \mathrm{ml}$ acetate buffer $(\mathrm{pH} 4.8), 1 \%$ bovine hemoglobin compounded with $0.2 \mathrm{ml}$ acetate buffer $(\mathrm{pH} 4.8)$ ] and incubated at $38^{\circ} \mathrm{C}$ for $60 \mathrm{~min}$. One $\mathrm{ml}$ of a $10 \%$ trichloroacetic acid solution was added to stop the reaction. The supernatant collected by centrifugation $(4,000 \mathrm{~g}$ for $5 \mathrm{~min}$ ) was used for amino acid content analysis by ninhydrin assay (Yemm et al., 1955), and peptidase activity was expressed as $\mu \mathrm{mol}$ amino acid $\mathrm{g}^{-1}$ boll shell fresh weight $\mathrm{h}^{-1}$.

\section{Statistics}

The analysis of variance (ANOVA) in SAS 9.4 (SAS Institute, 1989) was employed to determine statistical significance between means. Multiple mean comparisons were evaluated by LSD test at $p<0.05$. The correlations were assessed by calculation of the Pearson correlation coefficient.

\section{RESULTS}

\section{Boll Number per Plant, Boll Volume, and Boll Weight with Increasing Nitrogen Application under Nitrogen Deficiency}

In 2015, with the increasing amount of nitrogen application under nitrogen deficiency, more bolls per plant were detected in both cultivars, and this trend was observed during the whole recorded growing period (Table 1). At $40 \mathrm{DAF}$, when compared with the control treatment $(\mathrm{CK}, 0 \mathrm{~kg} / \mathrm{ha} \mathrm{N})$, the nitrogen application treatments $1 / 4 \mathrm{~N}(75 \mathrm{~kg} / \mathrm{ha} \mathrm{N}), 1 / 2 \mathrm{~N}(150 \mathrm{~kg} / \mathrm{ha} \mathrm{N})$, $3 / 4 \mathrm{~N}(225 \mathrm{~kg} / \mathrm{ha} \mathrm{N})$, and $\mathrm{N}$ (300 kg/ha N) increased boll number per plant by $106.3,133.3,158.7$, and $181 \%$ in SK-1, and by $122.8,150.9,203.5$, and $268.4 \%$ in SK-3. In 2016, similar trend was detected in boll number per plant under different nitrogen application dose (Table 1). However, the extent of increase was not as great as that in 2015. At $40 \mathrm{DAF}$, the nitrogen application treatments $1 / 4 \mathrm{~N}, 1 / 2 \mathrm{~N}, 3 / 4 \mathrm{~N}$, and $\mathrm{N}$ increased boll number per plant by $15.4,30.3,37.7$, and $47.0 \%$ in SK-1 and by 16.8, 28.7, 40.5 , and $66.8 \%$ in SK-3. The increase of boll number caused by increasing nitrogen dose was greater in SK-3 than SK-1, suggesting SK-3 boll number was more sensitive to nitrogen dose.

In 2015 and 2016, the individual boll volume was enhanced together with increasing dose of nitrogen application under nitrogen deficiency in both cultivars (Table 2). In 2015, nitrogen application treatments $1 / 4 \mathrm{~N}, 1 / 2 \mathrm{~N}, 3 / 4 \mathrm{~N}$, and $\mathrm{N}$ increased boll volume by $9.2,12.9,14.7$, and $15.6 \%$ in SK-1 and by 3.0 , 8.9, 11.9 , and $15.8 \%$ in SK-3 at 40 DAF. In the year 2016, the increase caused by nitrogen application treatments $1 / 4 \mathrm{~N}$, $1 / 2 \mathrm{~N}, 3 / 4 \mathrm{~N}$, and $\mathrm{N}$ on boll volume was $14.9,22.1,32.9$, and $41.7 \%$ in SK-1 and $11.4,19.7,24.5$, and $37.1 \%$ in SK-3 at 40 DAF.

In 2015 and 2016, the individual boll dry weight was increased under high nitrogen dose in both cultivars (Table 3). In 2015 , nitrogen application treatments $1 / 4 \mathrm{~N}, 1 / 2 \mathrm{~N}, 3 / 4 \mathrm{~N}$, and $\mathrm{N}$ increased the boll weight by $6,14,36.5$, and $44.7 \%$ in SK1 and by $10.4,23,31.3$, and $39.4 \%$ in SK-3 at 40 DAF. In the year 2016, the increase caused by nitrogen application treatments $1 / 4 \mathrm{~N}, 1 / 2 \mathrm{~N}, 3 / 4 \mathrm{~N}$, and $\mathrm{N}$ on boll weight was $7.4,21.7,27.4$, and $30.6 \%$ in SK-1 and $10.2,17.2,22.1$, and $27.1 \%$ in SK-3 at 40 DAF.

TABLE 1 | The effect of the nitrogen level on the boll number per plant of the two Bt cotton cultivars in 2015 and 2016.

\begin{tabular}{|c|c|c|c|c|c|c|c|c|c|}
\hline Cultivar & $\mathrm{N}$ rate $(\mathbf{k g} / \mathbf{h a})$ & \multicolumn{4}{|c|}{2015} & \multicolumn{4}{|c|}{2016} \\
\hline \multirow{3}{*}{ SK-1 } & 75 & $4.3 \mathrm{bcd}$ & 6.0de & $10.3 e$ & 13.0de & $7.87 \mathrm{~cd}$ & $9.67 d$ & $14.60 \mathrm{c}$ & $16.53 \mathrm{de}$ \\
\hline & 150 & $5.0 \mathrm{bcd}$ & $7.0 \mathrm{~cd}$ & $14.0 d$ & $14.7 \mathrm{c}$ & $8.27 b c$ & $10.87 \mathrm{~cd}$ & $15.13 \mathrm{bc}$ & $18.67 \mathrm{c}$ \\
\hline & 225 & $5.3 a b c$ & $8.0 \mathrm{bc}$ & $16.7 \mathrm{bc}$ & $16.3 b$ & $8.40 \mathrm{bc}$ & $11.80 \mathrm{bc}$ & $16.07 \mathrm{bc}$ & $19.73 c$ \\
\hline \multirow[t]{5}{*}{ SK-3 } & $\mathrm{O}(\mathrm{CK})$ & $2.7 e$ & $3.3 f$ & $7.0 f$ & $5.7 f$ & $6.73 d$ & $9.47 d$ & $11.47 d$ & $13.47 f$ \\
\hline & 75 & 4.0cde & $6.3 d$ & $12.0 \mathrm{e}$ & $12.7 \mathrm{e}$ & $8.40 \mathrm{bc}$ & $10.60 \mathrm{~cd}$ & $12.93 d$ & $15.73 e$ \\
\hline & 150 & $4.7 \mathrm{bcd}$ & $7.0 \mathrm{~cd}$ & $15.7 \mathrm{~cd}$ & $14.3 \mathrm{~cd}$ & $9.20 a b c$ & $11.80 \mathrm{bc}$ & $14.47 \mathrm{c}$ & $17.33 d$ \\
\hline & 225 & $5.7 a b c$ & 9.0ab & 18.3ab & $17.3 b$ & $9.27 a b$ & 12.73ab & $15.47 \mathrm{bc}$ & $18.93 \mathrm{c}$ \\
\hline & 300 & 6.0ab & $9.7 a$ & $20.3 a$ & $21.0 \mathrm{a}$ & $10.47 a$ & $14.00 \mathrm{a}$ & 16.60ab & $22.47 a$ \\
\hline
\end{tabular}

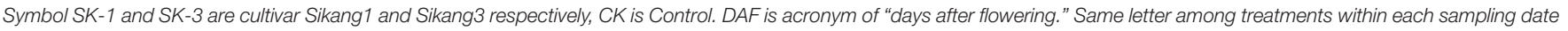
represent non-significant difference ( $L S D$ test at 0.05 significance level). 
TABLE 2 | The effect of the nitrogen level on the boll volume $\left(\mathrm{cm}^{3}\right)$ of the two Bt cotton cultivars in 2015 and 2016.

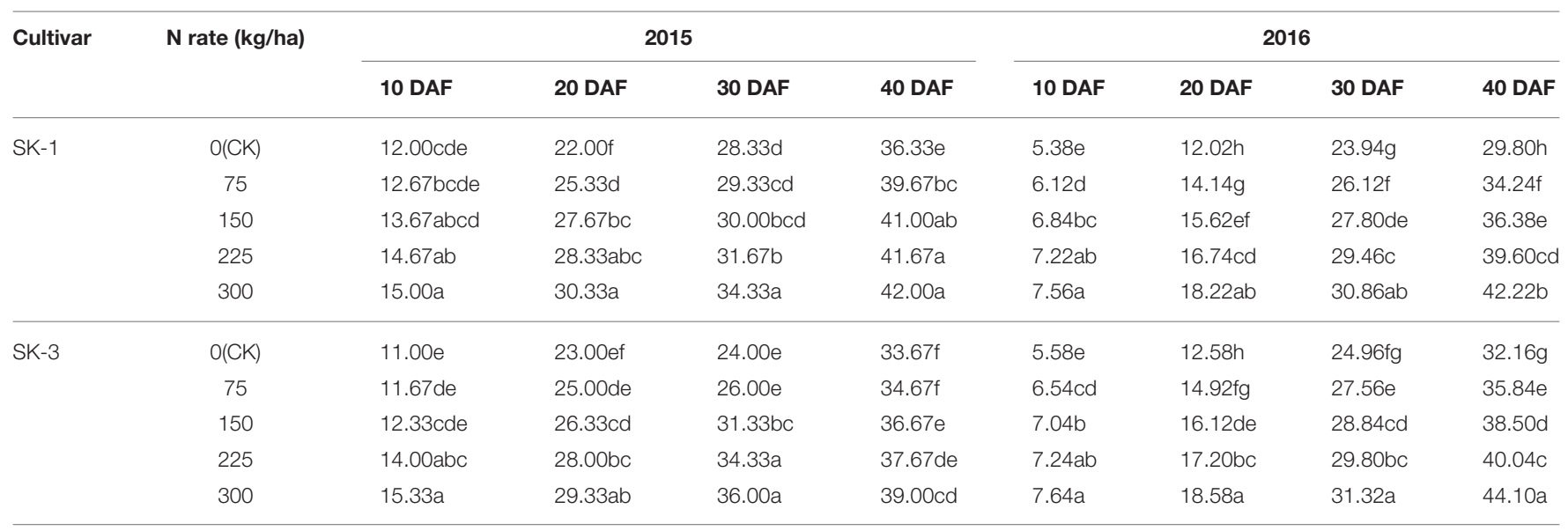

Symbol SK-1 and SK-3 are cultivar Sikang1 and Sikang3 respectively, CK is Control. DAF is acronym of "days after flowering." Same letter among treatments within each sampling date represent non-significant difference (LSD test at 0.05 significance level).

TABLE 3 | The effect of the nitrogen level on the boll dry weight (g) of the two Bt cotton cultivars in 2015 and 2016.

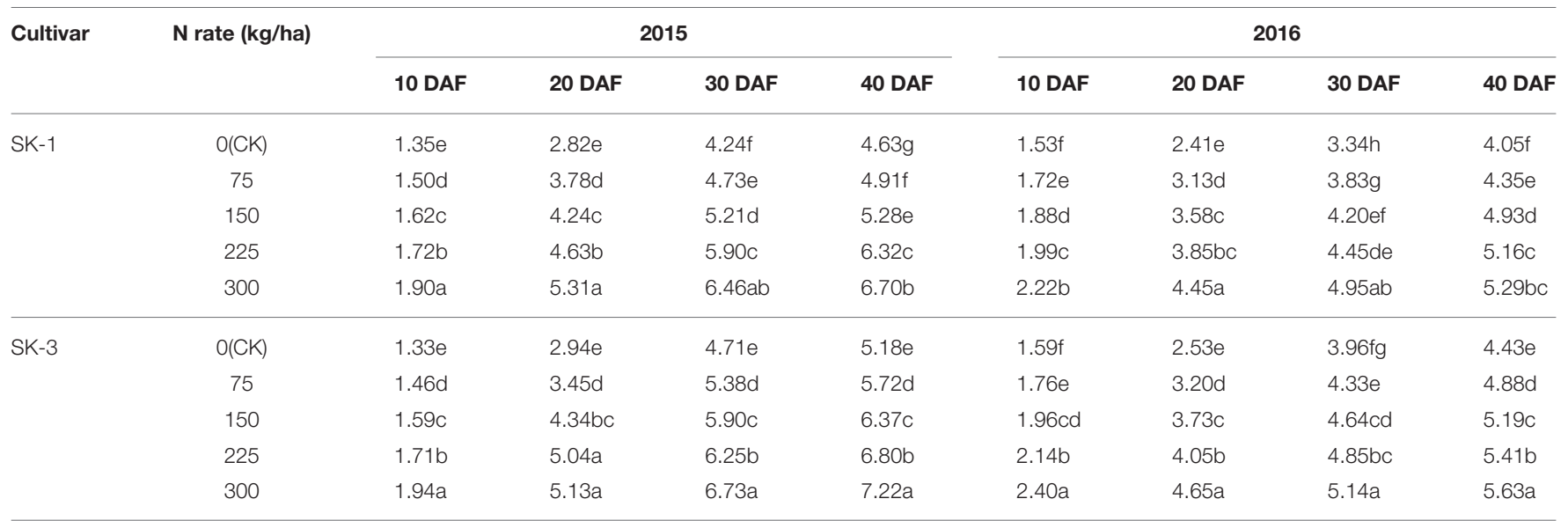

Symbol SK-1 and SK-3 are cultivar Sikang1 and Sikang3 respectively, CK is Control. DAF is acronym of "days after flowering." Same letter among treatments within each sampling date represent non-significant difference (LSD test at 0.05 significance level).

TABLE 4 | The effect of the nitrogen level on the boll shell Bt protein contents (ng g ${ }^{-1}$ FW) of the two Bt cotton cultivars in 2015 and 2016.

\begin{tabular}{|c|c|c|c|c|c|c|c|c|c|}
\hline Cultivar & $\mathrm{N}$ rate (kg/ha) & \multicolumn{4}{|c|}{2015} & \multicolumn{4}{|c|}{2016} \\
\hline \multirow{3}{*}{ SK-1 } & 75 & $127.78 c$ & $125.36 \mathrm{bc}$ & $150.90 \mathrm{~b}$ & 178.51b & $124.20 \mathrm{c}$ & $129.65 c$ & $160.42 \mathrm{c}$ & $184.56 d$ \\
\hline & 150 & $112.25 d$ & 113.55de & $129.87 \mathrm{c}$ & $150.21 \mathrm{~cd}$ & $115.71 \mathrm{de}$ & $122.74 \mathrm{e}$ & $136.32 f$ & $160.29 \mathrm{e}$ \\
\hline & 225 & $96.15 f$ & $102.65 \mathrm{fg}$ & $116.36 \mathrm{e}$ & $144.76 d$ & $87.27 \mathrm{~g}$ & $109.58 \mathrm{~g}$ & $123.05 \mathrm{~g}$ & $145.51 \mathrm{~g}$ \\
\hline \multirow[t]{5}{*}{ SK-3 } & $\mathrm{O}(\mathrm{CK})$ & $143.52 a$ & $144.73 a$ & 154.36b & $181.97 \mathrm{~b}$ & $144.14 a$ & $153.90 a$ & $166.18 \mathrm{~b}$ & $223.88 a$ \\
\hline & 75 & $127.63 c$ & $132.86 \mathrm{~b}$ & $135.32 \mathrm{c}$ & $156.34 c$ & $137.06 \mathrm{~b}$ & $144.30 \mathrm{~b}$ & $157.69 d$ & $211.21 \mathrm{~b}$ \\
\hline & 150 & $113.04 d$ & $121.02 \mathrm{~cd}$ & 123.61d & $145.81 d$ & $118.77 \mathrm{~cd}$ & $126.40 d$ & $149.63 e$ & $189.80 c$ \\
\hline & 225 & $103.11 \mathrm{e}$ & 107.52ef & $117.20 \mathrm{e}$ & $126.04 \mathrm{e}$ & $110.00 \mathrm{e}$ & $117.53 f$ & $135.99 f$ & $159.66 \mathrm{e}$ \\
\hline & 300 & $77.58 \mathrm{~h}$ & $99.84 \mathrm{fg}$ & $100.11 f$ & $119.25 \mathrm{e}$ & $99.20 f$ & $107.09 \mathrm{~g}$ & $123.32 \mathrm{~g}$ & $149.62 f$ \\
\hline
\end{tabular}

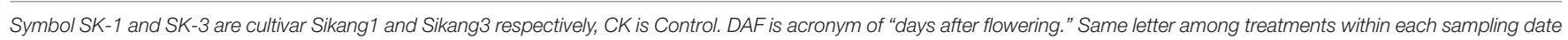
represent non-significant difference (LSD test at 0.05 significance level). 


\section{Boll Shell Insecticidal Protein Concentration with Increasing Nitrogen Application under Nitrogen Deficiency}

Enhanced boll shell Bt protein contents was observed during the growing season in both years, but the boll shell Bt protein contents decreased with increasing dose of nitrogen application under nitrogen deficiency in both cultivars (Table 4). In 2015, nitrogen application treatments $1 / 4 \mathrm{~N}, 1 / 2 \mathrm{~N}, 3 / 4 \mathrm{~N}$, and $\mathrm{N}$ decreased the boll shell Bt protein contents by 7.9, 22.5, 25.3, and $24.9 \%$ in SK-1 and by $14.1,19.9,30.7$, and $34.5 \%$ in SK-3 at 40 DAF. In the year 2016, the decline caused by nitrogen application treatments $1 / 4 \mathrm{~N}, 1 / 2 \mathrm{~N}, 3 / 4 \mathrm{~N}$, and $\mathrm{N}$ on boll shell insecticidal protein content was $11.4,23,30.1$, and $36.1 \%$ in SK-1 and 15.7, 15.2, 28.7, and $33.2 \%$ in SK-3 at 40 DAF. Higher boll shell Bt protein content was observed in 2016 than that in 2015.

\section{The Relationship between Boll Characteristics and Boll Shell Bt Contents with Increasing Nitrogen Application under Nitrogen Deficiency}

Cotton plants are more susceptible to boll worm at early boll development stage, which is around 20 DAF. At 20 DAF, significant negative correlation between boll number per plant and boll shell Bt toxin contents in $2015\left(r=-0.947^{* *}\right)$ and $2016\left(r=-0.753^{*}\right)$, boll volume and boll shell Bt toxin content in $2015\left(r=-0.989^{* *}\right)$ and $2016\left(r=-0.899^{* *}\right)$, boll dry weight and boll shell Bt toxin content in $2015\left(r=-0.977^{* *}\right)$ and $2016\left(r=-0.914^{* *}\right)$ was detected under different nitrogen dose under nitrogen deficiency (Figure 1). The correlation was highest between $\mathrm{Bt}$ contents with boll weight, followed by $\mathrm{Bt}$ contents with boll volume, and lowest between Bt contents and boll number during the whole growing period (data not shown). Higher correlation was observed in 2015 than 2016, but no differences was noted between cultivars SK1 and SK3 (data not shown). Thus, boll dry weight had better correlation with boll shell Bt contents, especially in 2015.

\section{Boll Shell Nitrogen Metabolism with Increasing Nitrogen Application under Nitrogen Deficiency}

Enhanced boll shell amino acid and soluble protein content was observed during the growing season for both years. However, the boll shell soluble protein concentration was decreased and the boll shell amino acid content was enhanced with increasing dose of nitrogen application under nitrogen deficiency in both cultivars (Tables 5, 6). Greater increase of amino acid content during the growing season was detected under low nitrogen application rate, and less increase was observed under high nitrogen application rate. The increase was $32.4 \%$ in SK-1 and $54.9 \%$ in SK-3 from 10 to 40 DAF for treatment CK, in contrast, the increase was only $26.9 \%$ in SK-1 and $37.9 \%$ in SK-3 for treatment $\mathrm{N}(300 \mathrm{~kg} / \mathrm{ha})$ in 2015 . For the year 2016, the value of increase from 10 to 40 DAF was $48.0 \%$ in SK-1 and $42.0 \%$ in SK-3 under treatment CK, and $32.0 \%$ in SK-1 and $26.8 \%$ in SK-3 under treatment $\mathrm{N}(300 \mathrm{~kg} / \mathrm{ha})$.

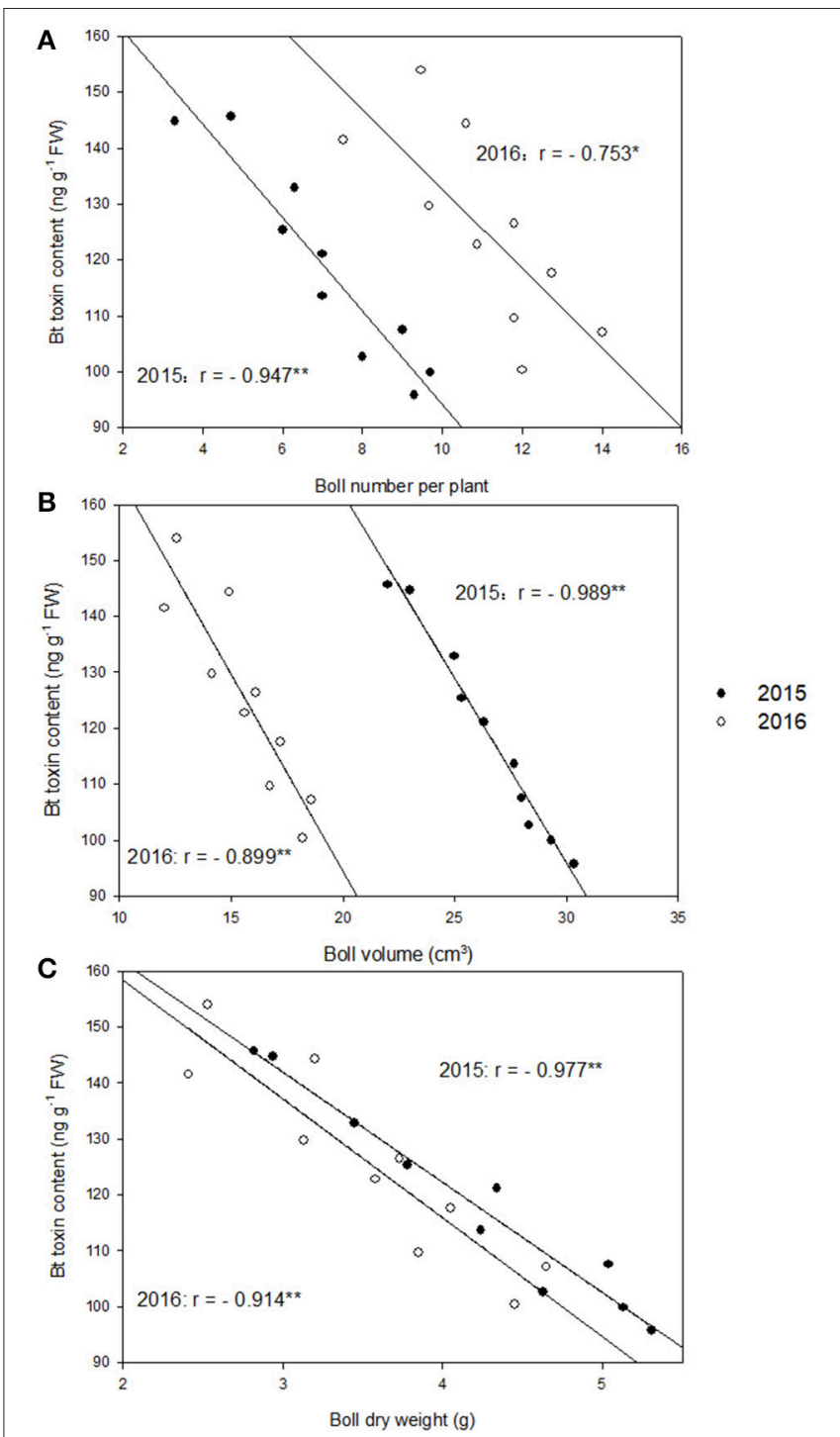

FIGURE 1 | Correlations between boll shell Bt toxin content and boll number per plant (A), boll shell Bt toxin content and boll volume (B), and boll shell Bt toxin content and boll dry weight (C) at 20 DAF (days after flowering) in 2015 and 2016. * and ** represent the significant level of 0.05 and 0.01 , respectively.

GPT and GOT, the key enzymes in amino acid synthesis, their activities decreased with increasing nitrogen application dose and increased during growing season (Tables 7, 8). Greater decline of the GOT activity with the increasing nitrogen application dose under nitrogen deficiency was detected at early growing season than late growing season in both cultivars and both years. By increasing nitrogen dose from 0 to $300 \mathrm{~kg} / \mathrm{ha}$, the GOT activity was decreased by $50.6 \%$ for SK- 1 and $39.7 \%$ for SK-3 at 10 DAF, but at 40 DAF the decrease was only $22 \%$ for SK-1 and $24.6 \%$ for SK-3 in 2015. In 2016, when nitrogen dose increased from 0 to $300 \mathrm{~kg} / \mathrm{ha}$, the GOT activity was decreased by $23.9 \%$ for SK-1 and $20.8 \%$ for SK-3 at 10 DAF, but at 40 DAF the decrease was only $16.6 \%$ for SK-1 and $16.1 \%$ for SK-3. Similar results for GPT activity was also detected in both cultivars in 2016. These 
TABLE 5 | The effect of the nitrogen level on the boll shell amino acid and soluble protein content of the two Bt cotton cultivars in 2015.

\begin{tabular}{|c|c|c|c|c|c|c|c|c|c|}
\hline Cultivar & $\mathrm{N}$ rate $(\mathbf{k g} / \mathrm{ha})$ & \multicolumn{4}{|c|}{ Amino acid content (mg g $\left.{ }^{-1} \mathrm{FW}\right)$} & \multicolumn{4}{|c|}{ Soluble protein content ( $\left.\mathrm{mg} \mathrm{g}^{-1} \mathrm{FW}\right)$} \\
\hline \multirow{3}{*}{ SK-1 } & 75 & $81.65 \mathrm{e}$ & $87.67 e$ & $106.13 f$ & 116.36de & $6.56 c$ & $9.80 \mathrm{~b}$ & $13.47 a$ & $14.35 b$ \\
\hline & 150 & $85.36 \mathrm{dc}$ & $93.26 d$ & $111.45 \mathrm{e}$ & $124.55 c$ & $6.12 d$ & $7.85 d$ & $11.21 \mathrm{c}$ & $13.13 \mathrm{c}$ \\
\hline & 225 & $94.92 b$ & $107.07 b$ & $125.42 \mathrm{c}$ & $132.62 b$ & $5.41 f$ & $6.37 f$ & $10.34 d$ & $11.96 \mathrm{~d}$ \\
\hline \multirow[t]{5}{*}{ SK-3 } & $\mathrm{O}(\mathrm{CK})$ & $50.78 i$ & $72.72 f$ & $96.79 \mathrm{~h}$ & $112.68 \mathrm{e}$ & $7.15 b$ & $9.87 \mathrm{~b}$ & $13.32 a$ & $15.01 \mathrm{a}$ \\
\hline & 75 & $60.60 \mathrm{~h}$ & $75.87 f$ & $100.91 \mathrm{~g}$ & $118.84 d$ & $6.55 \mathrm{c}$ & $8.27 \mathrm{c}$ & $12.50 \mathrm{~b}$ & $13.55 \mathrm{c}$ \\
\hline & 150 & $67.14 \mathrm{~g}$ & 89.01de & $106.57 f$ & $124.24 c$ & $6.32 \mathrm{~cd}$ & $7.73 d$ & $11.23 c$ & $12.46 d$ \\
\hline & 225 & 78.86ef & $97.98 c$ & $118.15 d$ & $134.35 b$ & $5.78 \mathrm{e}$ & $7.10 \mathrm{e}$ & $9.12 \mathrm{e}$ & $9.92 \mathrm{e}$ \\
\hline & 300 & $89.37 \mathrm{c}$ & $104.07 \mathrm{~b}$ & 130.92b & $143.95 a$ & $4.87 \mathrm{~g}$ & $6.11 f$ & $8.24 f$ & $8.56 f$ \\
\hline
\end{tabular}

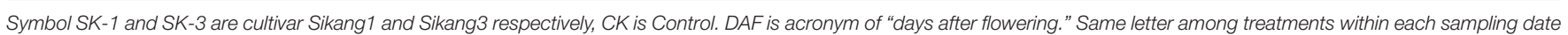
represent non-significant difference ( $L S D$ test at 0.05 significance level).

TABLE 6 | The effect of the nitrogen level on the boll shell amino acid and soluble protein content of the two Bt cotton cultivars in 2016.

\begin{tabular}{|c|c|c|c|c|c|c|c|c|c|}
\hline Cultivar & $\mathrm{N}$ rate $(\mathbf{k g} / \mathbf{h a})$ & \multicolumn{4}{|c|}{ Amino acid content ( $\left.\mathrm{mg} \mathrm{g}^{-1} \mathrm{FW}\right)$} & \multicolumn{4}{|c|}{ Soluble protein content $\left(\mathrm{mg} \mathrm{g}^{-1} \mathrm{FW}\right)$} \\
\hline \multirow{3}{*}{ SK-1 } & 75 & $100.69 f$ & 116.78ef & $155.53 f g$ & $173.03 \mathrm{e}$ & $9.44 \mathrm{~cd}$ & $18.08 \mathrm{c}$ & $21.21 b$ & $25.60 \mathrm{~b}$ \\
\hline & 150 & $125.09 \mathrm{e}$ & $136.84 d$ & 166.86de & $183.44 d$ & $8.47 \mathrm{e}$ & 16.33ef & $20.15 c$ & $23.60 c$ \\
\hline & 225 & $141.38 c$ & 152.32c & $176.48 \mathrm{~cd}$ & $210.25 b$ & $7.22 f$ & $15.80 f$ & $19.02 d$ & $23.21 c$ \\
\hline \multirow[t]{5}{*}{ SK-3 } & $\mathrm{O}(\mathrm{CK})$ & $95.58 f$ & $112.49 f$ & $144.72 \mathrm{~h}$ & $164.85 \mathrm{e}$ & $11.78 \mathrm{a}$ & $20.60 a$ & $23.03 a$ & $26.65 a$ \\
\hline & 75 & $117.88 \mathrm{e}$ & $123.27 e$ & 163.75 ef & $186.16 \mathrm{~cd}$ & $10.85 b$ & $19.11 b$ & $21.21 b$ & $25.87 \mathrm{ab}$ \\
\hline & 150 & $133.13 d$ & $145.05 \mathrm{~cd}$ & 172.83de & $193.79 c$ & $9.71 \mathrm{~cd}$ & $17.46 \mathrm{~cd}$ & $20.71 b c$ & $23.25 c$ \\
\hline & 225 & $151.46 b$ & $163.36 b$ & $185.76 \mathrm{bc}$ & $208.53 b$ & $9.19 \mathrm{de}$ & $16.91 \mathrm{de}$ & $20.14 c$ & $22.25 d$ \\
\hline & 300 & $164.37 a$ & $183.56 a$ & $202.20 a$ & $224.60 a$ & $7.41 f$ & $14.91 \mathrm{~g}$ & $18.70 d$ & $21.36 d$ \\
\hline
\end{tabular}

Symbol SK-1 and SK-3 are cultivar Sikang1 and Sikang3 respectively, CK is Control. DAF is acronym of "days after flowering." Same letter among treatments within each sampling date represent non-significant difference (LSD test at 0.05 significance level).

TABLE 7 | The effect of the nitrogen level on the boll shell glutamic-pyruvic transaminase (GPT) and glutamic-oxalacetic transaminase (GOT) activities of the two Bt cotton cultivars in 2015.

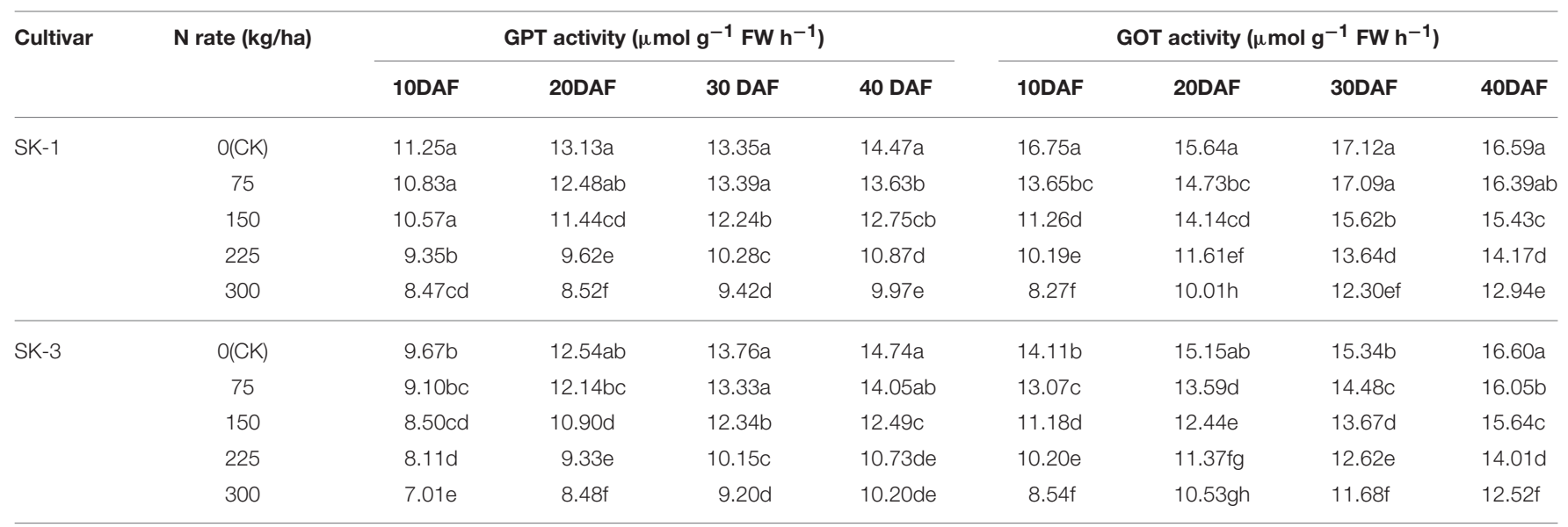

Symbol SK-1 and SK-3 are cultivar Sikang1 and Sikang3 respectively, CK is Control. DAF is acronym of "days after flowering." Same letter among treatments within each sampling date represent non-significant difference (LSD test at 0.05 significance level). 


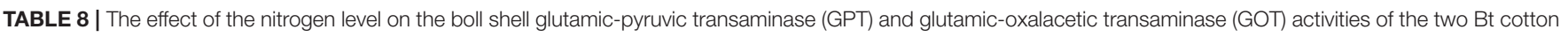
cultivars in 2016.

\begin{tabular}{|c|c|c|c|c|c|c|c|c|c|}
\hline \multirow[t]{2}{*}{ Cultivar } & \multirow[t]{2}{*}{$\mathrm{N}$ rate $(\mathrm{kg} / \mathrm{ha})$} & \multicolumn{4}{|c|}{ GPT activity ( $\left.\mu \mathrm{mol} \mathrm{g}^{-1} \mathrm{FW} \mathrm{h}^{-1}\right)$} & \multicolumn{4}{|c|}{ GOT activity ( $\mu \mathrm{mol} \mathrm{g}^{-1} \mathrm{FW} \mathrm{h}^{-1}$ ) } \\
\hline & & 10DAF & 20DAF & 30 DAF & 40 DAF & 10DAF & 20DAF & 30DAF & 40DAF \\
\hline \multirow[t]{5}{*}{ SK-1 } & $\mathrm{O}(\mathrm{CK})$ & $9.38 \mathrm{~b}$ & $10.55 a$ & $13.68 b$ & $16.02 \mathrm{a}$ & $10.90 \mathrm{a}$ & $11.73 a b$ & $15.33 b$ & 18.76ab \\
\hline & 75 & $8.95 d$ & $10.25 b$ & $13.16 d$ & $15.58 c$ & $10.42 \mathrm{bc}$ & $11.28 \mathrm{bc}$ & $14.91 b c$ & $17.95 \mathrm{~cd}$ \\
\hline & 150 & $8.61 e$ & $9.53 e$ & $12.44 f$ & $14.85 d$ & $10.05 c$ & 10.16ef & $14.29 c$ & 17.36de \\
\hline & 225 & $7.93 \mathrm{~h}$ & $8.87 \mathrm{~g}$ & $11.86 \mathrm{~g}$ & $14.19 \mathrm{e}$ & $8.96 d$ & $9.61 \mathrm{fg}$ & $13.51 d$ & $16.89 \mathrm{e}$ \\
\hline & 300 & $7.29 j$ & $8.39 i$ & $11.09 \mathrm{~h}$ & $13.68 \mathrm{~g}$ & $8.30 e$ & $9.36 \mathrm{~g}$ & $12.50 \mathrm{e}$ & $15.65 f$ \\
\hline \multirow[t]{5}{*}{ SK-3 } & $\mathrm{O}(\mathrm{CK})$ & $9.50 a$ & $10.33 b$ & $13.84 a$ & $16.18 \mathrm{a}$ & 10.65ab & $12.11 \mathrm{a}$ & $16.09 a$ & $18.94 a$ \\
\hline & 75 & $9.08 c$ & $10.10 \mathrm{c}$ & $13.34 c$ & $15.83 b$ & $10.18 \mathrm{c}$ & $10.92 \mathrm{~cd}$ & 15.54ab & 18.59abc \\
\hline & 150 & $8.47 f$ & $9.70 d$ & $12.96 \mathrm{e}$ & $14.86 \mathrm{~d}$ & $9.29 d$ & $10.88 \mathrm{~cd}$ & $14.45 c$ & $18.23 \mathrm{bc}$ \\
\hline & 225 & $8.16 \mathrm{~g}$ & $9.26 f$ & $11.93 \mathrm{~g}$ & $14.32 \mathrm{e}$ & $9.13 d$ & $10.51 \mathrm{de}$ & $13.60 d$ & $16.80 \mathrm{e}$ \\
\hline & 300 & $7.42 \mathrm{i}$ & $8.59 h$ & 11.19h & $13.84 f$ & $8.43 \mathrm{e}$ & 9.88ef & $13.08 \mathrm{de}$ & $15.89 f$ \\
\hline
\end{tabular}

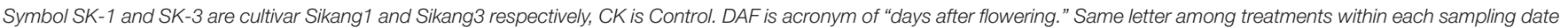
represent non-significant difference ( $L S D$ test at 0.05 significance level).

results indicated that the response of GOT and GPT activities to nitrogen dose was more sensitive at early growing season.

Boll shell protease and peptidase activities was enhanced significantly with increasing nitrogen application dose and during the growing season (Tables 9, 10). Greater increase during the growing season was observed at low nitrogen application rate than high nitrogen application rate for both enzyme activities in both years, with the only exception of protease activity in cultivar SK-3 in 2015.

\section{DISCUSSIONS}

\section{Nitrogen Application Enhanced Boll Development and Decreased Boll Shell Bt Toxin Content in N-Deficient Cotton}

Boll volume exhibited a significant negative correlation with boll shell Bt protein content in Bt cotton (Wang et al., 2009). Our present results revealed application of higher nitrogen dose recorded significantly enhanced boll number, boll volume, and boll weight, but reduced boll shell Bt protein content under nitrogen deficiency. Correlation analysis further confirmed a significant negative correlation of boll number, boll volume, and boll weight with boll shell Bt content. In addition, smaller bolls and higher Bt protein content was observed in 2016, and in 2015 larger bolls and lower Bt protein concentration was detected. In our present study the nitrogen application dose range was 0 to $300 \mathrm{~kg} / \mathrm{ha}$, and the recommended nitrogen application dose for local area is $300 \mathrm{~kg} / \mathrm{ha}$, which means nitrogen supply was in deficit conditions. The possible explanation for the reduced insecticidal concentration in boll shell with increased nitrogen application under nitrogen deficiency is the uneven nitrogen distribution in cotton bolls. Although nitrogen application rate was enhanced, the increase of nitrogen in boll shell was limited because more nitrogen was transported and assimilated inside the boll shell. This hypothesis was confirmed by our nitrogen content analysis during the growing season. For cultivar Sikang1, at $20 \mathrm{DAF}$, the nitrogen contents in boll shell, seed, and fiber were $1.67,2.12$, and $0.76 \%$ under control, and $2.37,3.21$, and $1.02 \%$ respectively under $150 \mathrm{~kg} / \mathrm{ha} \mathrm{N}$, and the nitrogen contents of boll shell, seed, and fiber increased to 2.51, 3.92, and $1.11 \%$ respectively under $225 \mathrm{~kg} / \mathrm{ha} \mathrm{N}$. The nitrogen content was enhanced by $5.9,22.1$, and $8.8 \%$ respectively in boll shell, seed, and fiber by increasing nitrogen from 150 to $225 \mathrm{~kg} / \mathrm{ha}$. When nitrogen application dose increased from 0 to $225 \mathrm{~kg} / \mathrm{ha}$, the nitrogen content was increased by $50,84.9$, and $31 \%$ respectively in boll shell, seed, and fiber. Thus, it is suggested that most of nitrogen was transported and assimilated in cotton seed instead of boll shell as nitrogen dose increased under nitrogen deficiency. And in fast developing bolls, the limited amount of nitrogen in boll shell may mainly be used for boll shell growth requirement, and thus the insecticidal protein as the exotic protein decreased in boll shell.

\section{Boll Shell Protein Synthesis and Degradation Affected Boll Development and Bt Content}

The increased nitrogen application under nitrogen deficiency significantly enhanced boll shell amino acid content, protease and peptidase activities, but decreased soluble protein content, GPT and GOT activities. It is evident that boll shell protein degradation was enhanced, and synthesis was reduced markedly with increasing nitrogen application in boll shell under nitrogen deficiency. Thus, both reduced synthesis and enhanced decomposition of boll shell protein contributed to the reduced protein concentration. As a part of the total soluble protein, Bt protein in boll shell also declined with increasing nitrogen application dose, and this reduction was a net result of reduced protein synthesis and increased protein degradation. In our present study, boll shell Bt protein content had a significant negative correlation with amino acid content in 2015 ( $r=$ $\left.-0.905^{* *}\right)$ and $2016\left(r=-0.866^{* *}\right)$, and a significant positive correlation with soluble protein content in $2015\left(r=0.930^{* *}\right)$ and $2016\left(r=0.981^{* *}\right)$ at 20 DAF. Our results were consistent with previous studies. Cotton leaf soluble protein and insecticidal 
TABLE 9 | The effect of the nitrogen level on the boll shell protease and peptidase activities of the two Bt cotton cultivars in 2015.

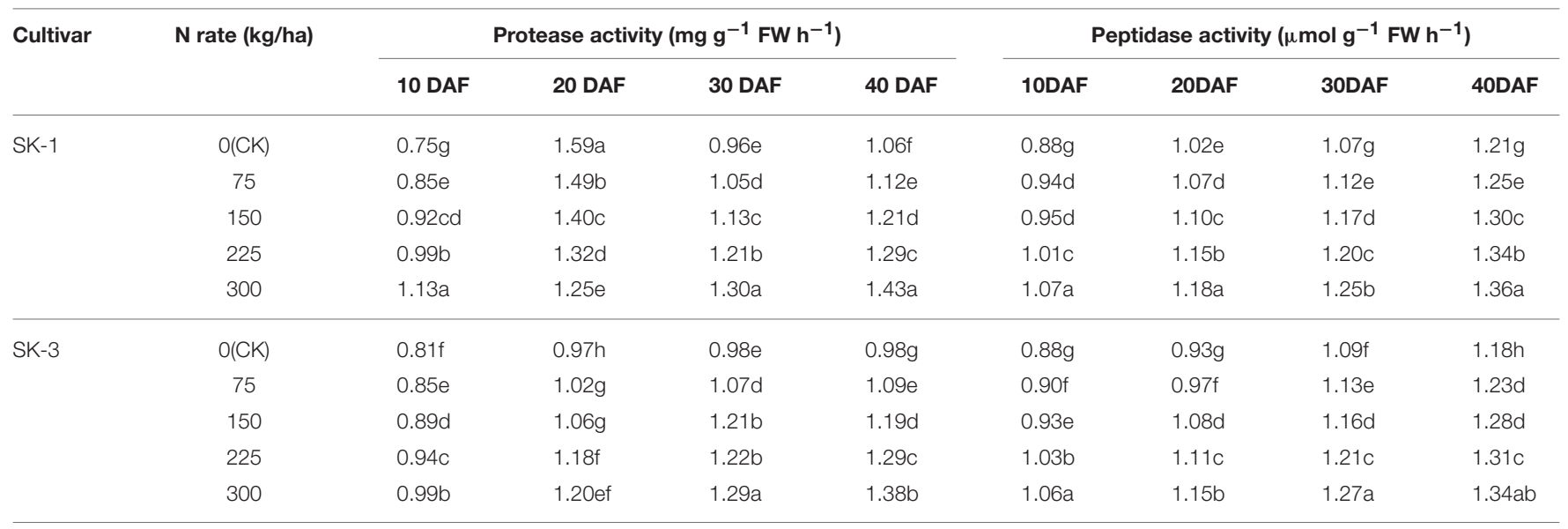

Symbol SK-1 and SK-3 are cultivar Sikang1 and Sikang3 respectively, CK is Control. DAF is acronym of "days after flowering." Same letter among treatments within each sampling date represent non-significant difference (LSD test at 0.05 significance level).

TABLE 10 | The effect of the nitrogen level on the boll shell protease and peptidase activities of the two Bt cotton cultivars in 2016.

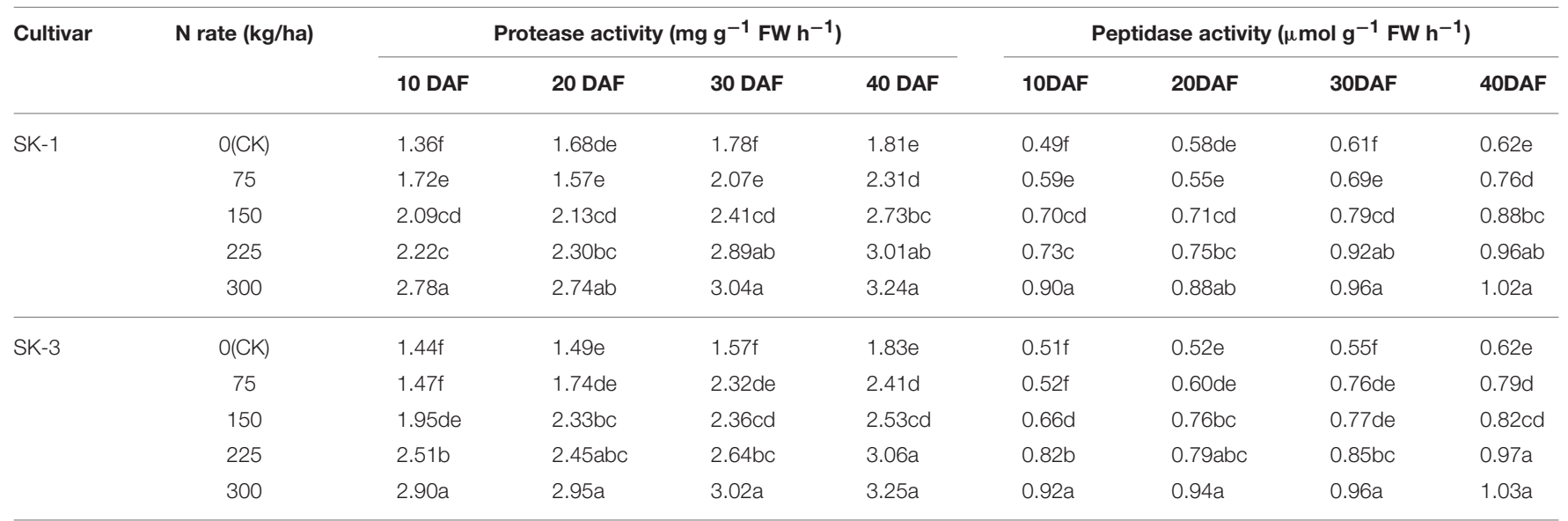

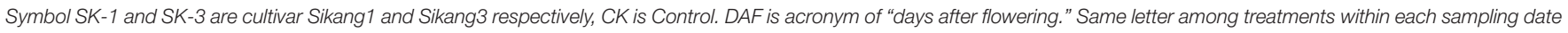
represent non-significant difference ( $L S D$ test at 0.05 significance level).

protein both reduced after exposing to high temperature, and this decrease was related to altered nitrogen metabolism (Chen et al., 2005, 2013). Extreme humidity also had a significant impact on leaf nitrogen metabolism, which resulted in to leaf soluble protein reduction and Bt protein decrease (Chen et al., 2012a,b). Therefore, the decline of boll shell insecticidal protein associated with increasing nitrogen dose under nitrogen deficiency was a net result of altered protein degradation and synthesis process.

In contrast to negative correlation between boll development and Bt content detected in our present study, positive correlation between square development and Bt content was observed in our previous square development study (Chen et al., 2017). The different relationship between reproductive organ development and Bt toxin content may be explained by the altered metabolism strength during different cotton growth stage: the strong carbohydrate metabolism and weak nitrogen metabolism during boll period; and the weak carbohydrate metabolism and strong nitrogen metabolism during square stage. Because sufficient nitrogen supply is critical for both boll growth and Bt protein synthesis (Guinn, 1986), strong nitrogen metabolism during square period guaranteed the requirement of both the square development and Bt protein synthesis. However, during boll stage, week nitrogen metabolic strength caused the competition for nitrogen between boll development and Bt protein synthesis. The fact that Bt protein as an exotic protein made it less competitive, and nitrogen would be used to feed faster developing bolls first, and thus lower Bt content was detected in bigger bolls.

Our results indicated that enhanced boll growth and formation by cultural practice could decrease insecticidal protein content, and ultimately insect resistance at boll period. Therefore, boll development and Bt content should be balanced in order to get both yield and insect resistance, and boll growth and formation should be maintained at appropriate level to guarantee the insecticidal efficiency.

In conclusion, enhanced boll number, boll weight, and boll volume together with reduced boll shell Bt protein contents were observed with increasing nitrogen application under nitrogen deficiency. In addition, reduced boll soluble 
protein content, declined GPT and GOT activity, increased protease and peptidase activities, and enhanced free amino acid were observed with increasing nitrogen application. Our results suggested that uneven distribution of nitrogen in cotton bolls caused limited nitrogen content in boll shell, which decreased protein synthesis and enhanced protein degradation, and ultimately reduced insecticidal protein content in boll shell with increasing nitrogen application under nitrogen deficiency.

\section{AUTHOR CONTRIBUTIONS}

YC (first author) and DC designed the experiments and finished the manuscript; YC, XZ, and YL provided guidance and support. $\mathrm{MZ}, \mathrm{QR}$, and ZC carried out the experiments.

\section{REFERENCES}

Benedict, J. S., Sachs, E, W., Altman, D. R., Ring, D., Stone, T., and Sims, S. (1993). Impact of -endotoxin-producing transgenic cotton on insect-plant interactions with heliothis virescens and helicoverpa zea (Lepidoptera: Noctuidae). Enviro. Entomol. 22, 1-9. doi: 10.1093/ee/22.1.1

Boquet, D. J., and Breitenbeck, G. A. (2000). Nitrogen rate effect on partitioning of nitrogen and dry matter by cotton. Crop Sci. 40, 1685-1693. doi: $10.2135 /$ cropsci2000.4061685x

Boquet, D. J., Moser, E. B., and Breitenbeck, G. A. (1994). Boll weight and withinplant yield distribution in field-grown cotton given different levels of nitrogen. Agron. J. 86, 20-26. doi: 10.2134/agronj1994.00021962008600010005x

Bradford, M. M. (1976). A rapid and sensitive method for the quantitation of microgram quantities of protein utilizing the principle of protein-dye binding. Anal. Biochem. 72, 248-254. doi: 10.1016/0003-2697(76)90527-3

Chen, D., Ye, G., Yang, C., Chen, Y., and Wu, Y. (2005). The effect of high temperature on the insecticidal properties of bt cotton. Environ. Exp. Bot. 53, 333-342. doi: 10.1016/j.envexpbot.2004.04.004

Chen, S., Wu, J. Y., He, X. L., Huang, J. Q., Zhou, B. L., and Zhang, R. X. (1997). Quantification using elisa of Bacillus thuringiensis insecticidal protein expressed in the tissue of transgenic insect-resistant cotton. Jiangsu J. Agric. 13, 154-156.

Chen, Y., Chen, Y., Wen, Y., Zhang, X., and Chen, D. (2012a). The effects of the relative humidity on the insecticidal expression level of bt cotton during bolling period under high temperature. Field Crops Res. 137, 141-147. doi: 10.1016/j.fcr.2012.08.015

Chen, Y., Li, Y., Chen, Y., Abidallha, E. H. M. A., Hu, D., Li, Y., et al. (2017). Planting density and leaf-square regulation affected square size and number contributing to altered insecticidal protein content in bt cotton. Field Crops Res. 205, 14-22. doi: 10.1016/j.fcr.2017.02.004

Chen, Y., Wen, Y. J., Chen, Y., Cothren, J. T., Zhang, X., Wang, Y. H., et al. (2012b). Effects of extreme air temperature and humidity on the insecticidal expression level of bt cotton. J. Integr. Agric. 11, 1836-1844. doi: 10.1016/S2095-3119(12)60188-9

Chen, Y., Wen, Y., Chen, Y., Zhang, X., Wang, Y., and Chen, D. (2013). The recovery of bt toxin content after temperature stress termination in transgenic cotton. Span. J. Agric. Res. 11, 438-446. doi: 10.5424/sjar/2013112-2854

Dai, J. L., Dong, H. Z., Duan, L. S., Zhen-Huai, L. I., and He-Quan, L. U. (2012). Effects of nitrogen fertilization on bt cotton growth and bt protein concentration in leaves under salinity stress. Cotton Sci. 24, 303-311. doi: 10.3969/j.issn.1002-7807.2012.04.003

Dong, H. Z., Li, W. J., Tang, W., Li, Z. H., and Zhang, D. M. (2007). Heterosis in yield, endotoxin expression and some physiological parameters in bt transgenic cotton. Plant Breed. 126, 169-175. doi: 10.1111/j.1439-0523.2007. 01321.x

Gasser, C. S., and Fraley, R. T. (1989). Genetically engineering plants for crop improvement. Science 244, 1293-1299. doi: 10.1126/science.244.4910.1293

\section{ACKNOWLEDGMENTS}

We are grateful for the Projects \#31671613 and \#31471435 supported by National Natural Science Foundation of China, China Postdoctoral Science Foundation Grant (2016M591934), Innovative and Entrepreneurial doctor in Jiangsu Province, Project funded by the Priority Academic Program Development of Jiangsu Higher Education Institutions, China(PAPD), Project \#2017YFD0201306 supported by the National Key R\&D Program of China, Project 17KJA210003 supported by Jiangsu Province University Key Natural Science Research Project, Project SXGC(2016)320 supported by Three New Technology Foundation of Agriculture in Jiangsu Province (China), Project \#2016PCTS-1 supported by the Chinese academy of agricultural sciences' engineering science and technology innovation fund.

Gould, F. (1988). Evolutionary biology and genetically engineered crops: consideration of evolutionary theory can aid in crop design. Bioscience 38, 26-33. doi: 10.2307/1310643

Guinn, G. (1986). "Hormonal relations during reproduction," in Cotton Physiology, eds J. R. Mauney and J. M. Stewart (Memphis, TN: The Cotton Foundation), $113-136$.

Huang, J., Mi, J., Hai, L., Wang, Z., Chen, R., Hu, R., et al. (2010). A decade of bt cotton in chinese fields: assessing the direct effects and indirect externalities of bt cotton adoption in china. Sci. China. Life Sci. 53, 981-991. doi: 10.1007/s11427-010-4036-y

Li, Y. X., Greenberg, S. M., and Liu, T. X. (2006). Effects of bt cotton expressing crylac and cry2ab and non-bt cotton on behavior, survival and development of trichoplusia ni (lepidoptera: Noctuidae). Crop Prot. 25, 940-948. doi: 10.1016/j.cropro.2005.12.007

Manjunatha, S. B. (2015). Effect of nitrogen levels and potassium nitrogen ratios(k:N ratio) on endotoxin expression in bt cotton. Biochem. Cell. Arch. 15, 469-473.

Mcconnell, J. S., Baker, W. H., and Rcjr, K. (1998). Yield and petiole nitrate concentrations of cotton treated with soil-applied and foliar-applied nitrogen. J. Cotton Sci. 2, 143-152.

Moore, S. H. (1999). Nitrogen effect on position of harvestable bolls in cotton. J. Plant Nutr. 22, 901-909. doi: 10.1080/01904169909365681

Pettigrew, W. T., and Adamczyk, J. J. (2006). Nitrogen fertility and planting date effects on lint yield and crylac (bt) endotoxin production. Agron. J. 98, 691-697. doi: 10.2134/agronj2005.0327

SAS Institute (1989). SAS/STAT Software, Version 6, 4th Edn. Cary, NC: SAS Institute Inc.

Shen, P., Lin, K. J., Zhang, Y. J., Wu, K. M., and Guo, Y. Y. (2010). Seasonal expression of Bacillus thuringiensis insecticidal protein and control to cotton bollworm in different varieties of transgenic cotton. Cotton Sci. 22, 393-397. doi: 10.3969/j.issn.1002-7807.2010.05.002

Stone, G. D. (2011). Field versus farm in warangal: Bt cotton, higher yields, and larger questions. World Dev. 39, 387-398. doi: 10.1016/j.worlddev.2010.09.008

Tonhazy, N. E., White, N. G., and Umbriet, W. W. (1950). Colorimetric assay of glutamic-pyruvic transaminase. Arch. Biochem. Biophys. 28, 36-38.

Vance, C. P., and Johnson, L. E. (1979). Nitrogen fixation, nodule development, and vegetative regrowth of alfalfa (medicago sativa 1.) following harvest. Plant Physiol. 67, 1198-1203. doi: 10.1104/pp.64.1.1

Wang, Y. H., Ye, G. Y., Luan, N., Xiao, J., Chen, Y., and Chen, D. H. (2009). Boll size affects the insecticidal protein content in Bacillus thuringiensis (bt) cotton. Field Crops Res. 110, 106-110. doi: 10.1016/j.fcr.2008.07.008

Xia, L. Q., and Guo, S. D. (2004). High temperature on bt gene expression of bt cotton. Sci. Agric. Sin. 11, 1733-1737. doi: 10.3321/j.issn:0578-1752.2004.11.027

Yang, C. Q., Li-Hua, X. U., and Yang, D. Y. (2005). Effects of nitrogen fertilizer on the bt-protein content in transgenic cotton and nitrogen metabolism mechanism. Cotton Sci. 41, 227-231. doi: 10.3969/j.issn.1002-7807.2005. 04.007 
Yemm, E. W., Cocking, E. C., and Ricketts, R. E. (1955). The determination of amino-acids with ninhydrin. Analyst 80, 209-214. doi: 10.1039/an9558 000209

Zhang, G., and Wen, S. (2011). Effects of salt stress on bt protein content and nitrogen metabolism of transgenic bt cotton. Acta Agric. Boreali Occidentalis Sin. 20, 106-109. doi: 10.3969/j.issn.1004-1389.2011. 06.023

Zhang, X., Zhang, L., Ye, G., Wang, Y., Chen, Y., and Chen, D. (2007). The impact of introducing the Bacillus thuringiensis gene into cotton on boll nitrogen metabolism. Environ. Exp. Bot. 61, 175-180. doi: 10.1016/j.envexpbot.2007.05.008
Conflict of Interest Statement: The authors declare that the research was conducted in the absence of any commercial or financial relationships that could be construed as a potential conflict of interest.

Copyright (๑) 2018 Chen, Li, Zhou, Rui, Cai, Zhang, Chen and Chen. This is an open-access article distributed under the terms of the Creative Commons Attribution License (CC BY). The use, distribution or reproduction in other forums is permitted, provided the original author(s) and the copyright owner are credited and that the original publication in this journal is cited, in accordance with accepted academic practice. No use, distribution or reproduction is permitted which does not comply with these terms. 